\author{
N. Ambrosino, N. Carpenè and M. Gheradi \\ Pulmonary Division, Cardio-Thoracic Dept, Azienda \\ Ospedaliera, Universitaria Pisana, Pisa, Italy.
}

Correspondence: N. Ambrosino, Pulmonary Division, CardioThoracic Dept, Azienda Ospedaliera, Universitaria Pisana, via Paradisa 2, Cisanello, Pisa, 56124, Italy. E-mail: n.ambrosino@ aopisa.toscana.it

Statement of Interest: A statement of interest for this manuscript can be found at www.erj.ersjournals.com $/ \mathrm{misc} /$ statements.dtl

\section{REFERENCES}

1 Ambrosino N, Carpenè N, Gherardi M. Chronic respiratory care for neuromuscular diseases in adults. Eur Respir J 2009; 34: 444-451.
2 Bach JR. A comparison of long-term ventilatory support alternatives from the perspective of the patient and care giver. Chest 1993; 104: 1702-1706.

3 Bach JR, Alba AS, Saporito LR. Intermittent positive pressure ventilation via the mouth as an alternative to tracheostomy for 257 ventilator users. Chest 1993; 103: 174-182.

4 Bach JR. The Management of Patients with Neuromuscular Disease. Philadelphia, Elsevier 2004; pp. 289-296.

5 Bach JR, Goncalves MR, Hamdani I, et al. Extubation of patients with neuromuscular disease: a new management paradigm. Chest 2009; [Epub ahead of print PMID: 20040608].

6 Marchese S, Corrado, Scala R, et al. Tracheostomy in patients with long-term mechanical ventilation: a survey. Respir Med 2010; [Epub ahead of print PMID: 20122822].

7 Frutos-Vivar F, Esteban A, Apezteguia C, et al. Outcome of mechanically ventilated patients who require a tracheostomy. Crit Care Med 2005; 33: 290-298.

\title{
Exercise capacity in chronic respiratory diseases
}

\section{To the Editors:}

We read with great interest the paper by SwALLow et al. [1], comparing skeletal muscle function in chronic obstructive pulmonary disease (COPD) patients and patients with idiopathic scoliosis. In our opinion, the reported muscular weakness in patients with a chronic noninflammatory respiratory disease may have important implications in rehabilitation and prevention of chronic respiratory diseases.

Pulmonary rehabilitation is defined as an "evidence-based, multidisciplinary, comprehensive intervention for patients with chronic respiratory diseases..." [2], but most of the scientific literature is about COPD patients, with less attention devoted to other chronic respiratory diseases. In COPD patients, the cause of skeletal muscle limitation is a subject of debate; whether the reduction of physical activity is because of the respiratory symptoms or the so-called systemic effects of the disease [2]. If, as suggested by SwALLOW et al. [1], the common determinant of muscular impairment in COPD and scoliosis is the deconditioning caused by the disease, there is a basis for pulmonary rehabilitation in the majority of patients with chronic pulmonary disease, regardless of the cause. Recently, good results have been reported in the rehabilitation of patients with non-COPD respiratory diseases, such as interstitial lung diseases including idiopathic pulmonary fibrosis [3]. Furthermore, rehabilitation is possible in patients previously excluded by this kind of treatment, such as those with pulmonary hypertension [4].

Another interesting topic is the prevention of loss of exercise capacity in pulmonary patients. Recently, we described the case of a 70-yr-old COPD patient who, having exercised regularly since a young age, maintained a good physical performance (peak oxygen uptake $130 \%$ of predicted) despite a significant pulmonary function limitation (forced expiratory volume in $1 \mathrm{~s} 60 \%$ pred) [5]. GARCIA-AYMERICH et al. [6] reported a reduced pulmonary function decline and reduced risk of COPD in smokers practising regular physical activity. The study by WATZ et al. [7] showed a reduction of physical activity across the Global Initiative for Chronic Obstructive Lung Disease (GOLD) stages in COPD patients. There is a significant body of evidence about the beneficial anti-inflammatory effect of exercise [8]. It is generally accepted that the amount of exercise required to prevent the loss of exercise capacity is less than that required to improve physical performance. If this is the case, in the future, much attention must be devoted to early diagnosis of chronic respiratory diseases to prevent the decline of exercise capacity, which is a major determinant of the quality of life of such patients, by a regular physical activity.

\section{G. Fiorenzano, C. Santoriello, V. Musella and M. Polverino} Fisiopatologia Respiratoria, Ospedale di Cava de' Tirreni, ASL Salerno, Italy.

Correspondence: G. Fiorenzano, Fisiopatologia Respiratoria, via Santoriello, 2, 84013 Cava de' Tirreni, Italy. E-mail: gxfiore@tiscali.it

Statement of Interest: None declared.

\section{REFERENCES}

1 Swallow EB, Barreiro E, Gosker H, et al. Quadriceps muscle strength in scoliosis. Eur Respir J 2009; 34: 1429-1435.

2 ATS/ERS Statement on pulmonary rehabilitation. Am J Respir Crit Care Med 2006; 173: 1390-1413.

3 Ferreira A, Garvey C, Connors GL, et al. Pulmonary rehabilitation in interstitial lung disease. Chest 2009; 135: 442-447.

4 Mereles D, Ehlken L, Kreuscher S, et al. Exercise and respiratory training improve exercise capacity and quality of life in patients 
with severe chronic pulmonary hypertension. Circulation 2006; 114 : 1482-1489.

5 Santoriello C, Fiorenzano G, Musella V, et al. Long-term physical training allows high exercise performance in moderate chronic obstructive pulmonary disease (COPD). J Sports Med Phys Fitness 2009; 49: 184-186.

6 Garcia-Aymerich J, Lange P, Benet M, et al. Regular physical activity modifies smoking-related lung function decline and reduces risk of chornic obstructive pulmonary disease: a population based cohort study. Am J Respir Crit Care Med 2007; 175: 458-463.

7 Watz H, Waschki B, Meyer T, et al. Physical activity in patients with COPD. Eur Respir J 2009; 33: 262-272.

8 Petersen AM, Pedersen BK. The anti-inflammatory effect of exercise J Appl Physiol 2005; 98: 1154-1162.

DOI: 10.1183/09031936.00204009 